\title{
DESAIN GENERATOR OZONE DENGAN TEKNOLOGI PLASMA DBD (Dielec- tric Barrier Discharge)
}

\author{
Ricky Aryadi ${ }^{1)}$, Supari ${ }^{2)}$, Harmini $^{3)}$ \\ ${ }^{1,2,3)}$ Program Studi Teknik Elektro, Fakultas Teknik, Universitas Semarang \\ Jalan Soekarno Hatta - Tlogosari, Semarang \\ *e-mail: ricky.guns.roses27@gmail.com ${ }^{1)}$, supary_p@yahoo.com ${ }^{2)}, \underline{\text { harmini@ @usm.ac.id }}^{3)}$
}

\begin{abstract}
Industrial sterilization is a very important problem. Ozone is a powerful oxidizer that can function for sterilization and is environmentally friendly. Plasma DBD (Dielectric Barrier Discharge) is one of the effective technologies to obtain ozone. The ozone generator currently uses a lot of manual control operations. Manual control uses a mechanical system in the form of a potentiometer to calibrate the frequency and output of the ozone generator output, so that digitization and automation are needed to operate to replace human labor. The design of the digital ozone control generator is done using an AVR microcontroller. Programming used in this research is basic language (BASCOM), then uses a DAC (Digital to Analog Converter) system which is the output of a Microcontroller with a Weighted Binnary Resistor. The output of the microcontroller is frequency and 8 bit digital with a decimal parameter of 200. The result of automation is that the timer works for 2 hours. The greater frequency the ozone produced. At a frequency of $1500 \mathrm{~Hz}$ the power produced is 308.58 watts with an ozone concentration of 59 ppm. Efficiency using a switching system $>90 \%$.
\end{abstract}

Keywords: Plasma, AVR Microcontroller, Ozone.

\begin{abstract}
ABSTRAK
Sterilisasi di bidang industri merupakan persoalan yang sangat penting. Ozone merupakan oksidator kuat yang dapat berfungsi untuk sterilisasi dan ramah lingkungan. Plasma DBD (Dielectric Barrier Discharge) merupakan salah satu teknologi yang efektif untuk memperoleh ozone. Generator ozone saat ini masih banyak menggunakan pengoperasian kendali manual. Kendali manual menggunakan sistem mekanik yang berupa potensiometer untuk mengkalibrasi frekuensi dan keluaran output generator ozone, sehingga dibutuhkan digitalisasi dan otomatisasi untuk pengoperasiannya untuk menggantikan tenaga kerja manusia. Rancang bangun generator ozone kendali digital dilakukan menggunakan mikrokontroller AVR. Pemrograman yang digunakan dalam penelitian ini adalah bahasa basic (BASCOM), Selanjutnya menggunakan sistem DAC (Digital to Analog Converter) yang merupakan output dari Mikrokontroller dengan Resistor Binnary Weighted. Output dari mikrokontroller berupa frekuensi dan 8 bit digital dengan parameter desimal sebesar 200. Hasil dari otomatisasi yaitu timer bekerja selama 2 jam. Semakin besar frekuensi semakin besar ozon yang dihasilkan. Pada frekuensi $1500 \mathrm{~Hz}$ daya yang dihasilkan sebesar 308,58 watt dengan kosentrasi ozon 59 ppm. Efisiensi menggunakan sistem switching >90\%.
\end{abstract}

Kata Kunci: Plasma, Mikrokontroller AVR, Ozone.

\section{Pendahuluan}

$\mathrm{S}$ terilisasi mempunyai peran penting di dalam industri kantor, toko obat, kimia, air, dan kesehatan tidak terlepas juga dapat mensterilisasi untuk bahan pangan[1]. Ozone merupakan unsur kimia yaitu $\mathrm{O}_{3}$ yang mampu untuk mensterilisasi dan ramah lingkungan. Di era Revolusi Industri 4.0 (awal mula belum ada kesepakatan), revolusi industri ini dicirikan dengan terintegrasinya berbagai konsep dan teknologi terkait dengan pengorganisasian rantai nilai industri[2]. Konsep inti dari industri 4.0 adalah Cyber Physical Systems (CPS), yang memungkinkan pemantauan proses fisik di pabrik/industri dalam lingkungan virtual, melalui digitalisasi dan penciptaan klon digital dari pabrik/industri pada proses komputasi, komunikasi, kontrol dan koordinasi. Digitalisasi dan otomatisasi mampu menjawab tantngan revolusi industry 4.0 yang semua industry maupun alat elektronik dapat dipantau dan dikontrol lewat jarak jauh dan dengan sistem close loop[1]. Terbentuknya ozone bisa menggunakan metode High Voltage yang ramah lingkungan. DBD (Dielectric Barrier Discharge) adalah salah satu teknologi yang efektif untuk produksi ozone. Terjadinya plasma adalah sebelum terbentuknya petir, tegangan tinggi diatas $15 \mathrm{KV}$ bisa menjadikannya sebuah petir. Pada range $1 \mathrm{KV}-10 \mathrm{KV}$ plasma ozon itu terbentuk[6].

Plasma sebagai gas yang terionisasi dalam lucutan listrik, jadi plasma dapat juga didefinisikan sebagai percampuran kuasi-netral dari elektron, radikal, ion positif dan negatif. Percampuran antara ion-ion yang bermuatan positif dengan elektron-elektron yang bermuatan negatif memiliki sifat-sifat yang sangat berbeda dengan gas pada umumnya dan materi pada fase ini disebut fase plasma. Secara sederhana plasma didefinisikan sebagai gas terionisasi dan dikenal sebagai fase materi ke empat setelah fase padat, cair, dan fase gas[5]. Pembuatan plasma tersebut di gunakan rangkaian yang 
bisa memunculkan tegangan tinggi untuk mencapai ribuan kilo volt. Pada penelitian ini prinsip elektronika step up inverter digunakan sebagai rangkaian yang digunakan untuk menghasilkan tegangan tinggi.

Pengaturan berbagai macam peralatan di industri diperlukan peralatan kontrol yang mampu beroperasi pada tegangan dan arus yang cukup besar. Elektronika Daya memberikan solusi terhadap permasalahan di dunia industri untuk dapat melakukan pengaturan peralatan dengan menggunakan rangkaian yang dapat bekerja dengan arus dan tegangan yang besar. Beberapa aplikasi di industry bekerja pada arus yang mencapai ratusan bahkan ribuan amper dan tegangan yang tinggi $220 \mathrm{~V}, 380 \mathrm{~V}, 600 \mathrm{~V}, 3,8 \mathrm{KV}$.

Saat ini industri terdapat banyak kontrol otomatisasi yaitu dengan PLC maupun Mikrokontroller. Mikrokontroller merupakan sebuah sistem komputerisasi yang dikemas dalam sebuah chip. Di dalamnya terdapat sebuah prosessor, memori (RAM,ROM,SRAM, dll) dan disertai dengan I/O. Mikrokontroler berbeda dari mikroprosesor serba guna yang digunakan dalam sebuah PC karena mikrokontroler memerlukan sebuah sistem minimum untuk memproses atau menjalankannya. Sistem minimum mikrokontroler adalah rangkaian elektronik minimum yang diperlukan untuk beroperasinya IC mikrokontroler. Sistem minimum ini kemudian bisa dihubungkan dengan rangkaian lain untuk menjalankan fungsi tertentu. Di keluarga mikrokontroler AVR, Atmega 16 adalah salah satu seri yang digunakan dalam penelitian ini. Oleh karena itu perlu dilakukan penelitian mengenai rancang bangun otomatisasi plasma DBD menggunakan Mikrokontroller AVR.

\section{PERANCANGAN PERALATAN}

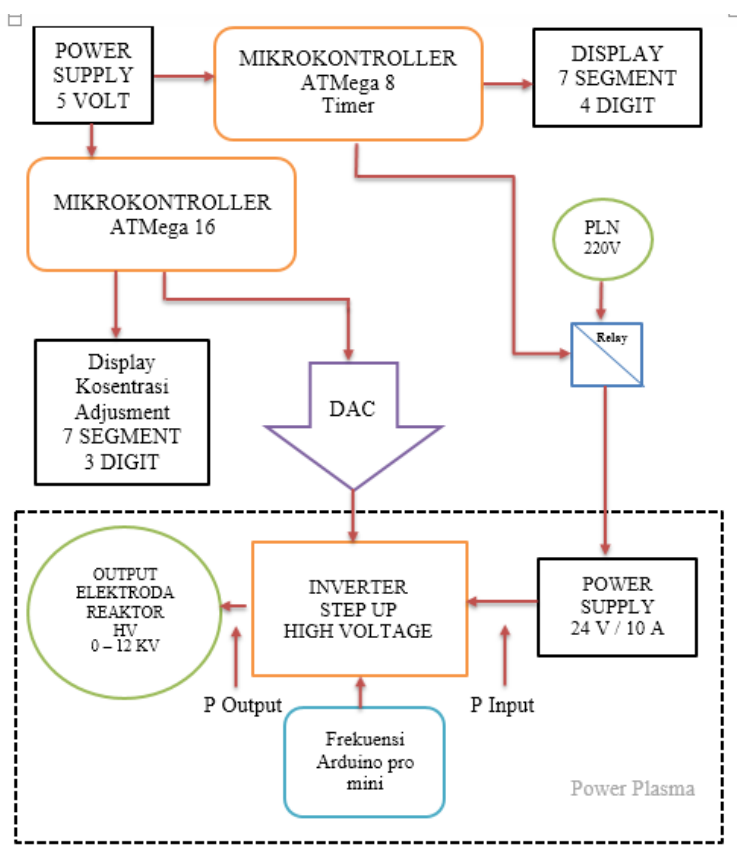

Gambar 1. Diagram Blok Rancang Bangun
Pada gambar 1 diagram skema rancang bangun terdiri dari power supply 5 volt untuk mensupply IC Atmega timer dan IC atmega 16 otomatisasi. Mikrokontroller timer berfungsi sebagai pewaktu, outpunya berupa display 7 segment dan sebuah relay untuk mengendalikan power. Mikrokontroller Atmega 16 otomatisasi berfungsi sebagai pengendali output DAC dan display kosentrasi pada 7 segment.

Diagram power plasma terdiri dari powersupply 24 volt. Inverter High Voltage sebagai rangkaian penaik tegangan. Terdapat osilator pada arduino pro sebagai pembangkit frekuensi pada step up high voltage, kemudian output dari inverter dimasukan ke reactor DBD yang meghasilkan plasma ozone. Didalam power plasma terdapat daya masukan dan daya keluar yang akan dihitung efisiensinya.

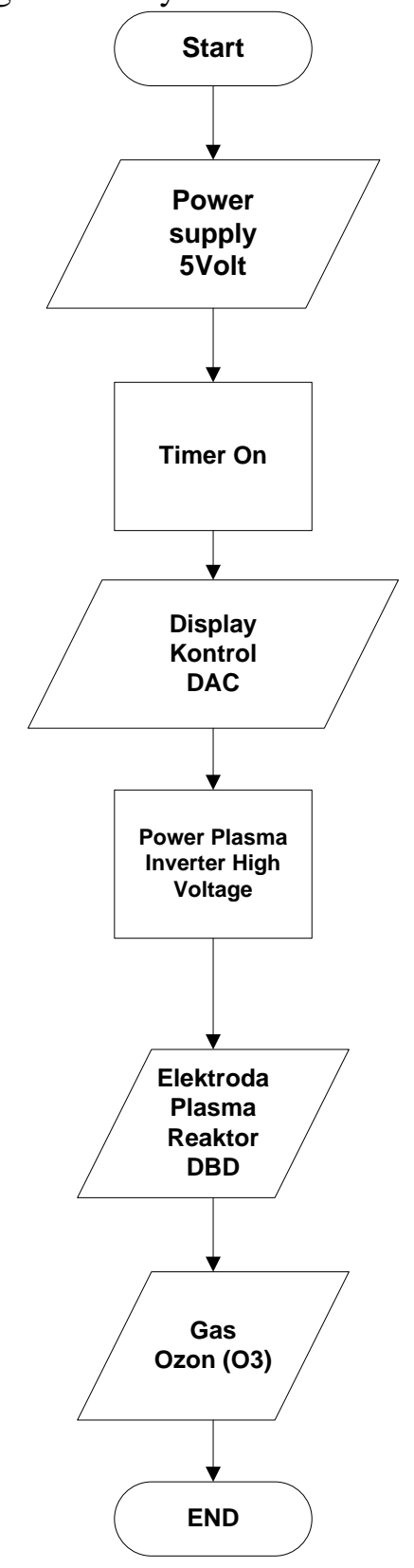

Gambar 2. Flowchart Rancang Bangun Generator Plasma Ozone Dengan Mikrokontroller Avr 
Diagram alir pada gambar 2 adalah flowchart Generator Plasma Ozon. Bertegangan 5 volt untuk mencatu daya IC kemudian akan menyalakan timer selama 2 jam untuk menghidupkan power plasma. Ic atmega 16 akan mengotomatisasi DAC dan nilai didalam program sesuai EEPROM. DAC akan diproses dan masuk keinput analog inverter High voltage. Output high voltage terhubung dengan reactor DBD yang merupakan penghasil ozon $\left(\mathrm{O}_{3}\right)$.

\section{Rangkaian Timer}

Pada penelitian ini, pertama yang dibuat yaitu perencanaan sistem digital, untuk menghindari over heat pada generator plasma ozone, diperlukan rangkaian timer digital, pembuatan skema rangkaian menggunakan software diptrace scematic atau bisa menggunakan software proteus 8.0

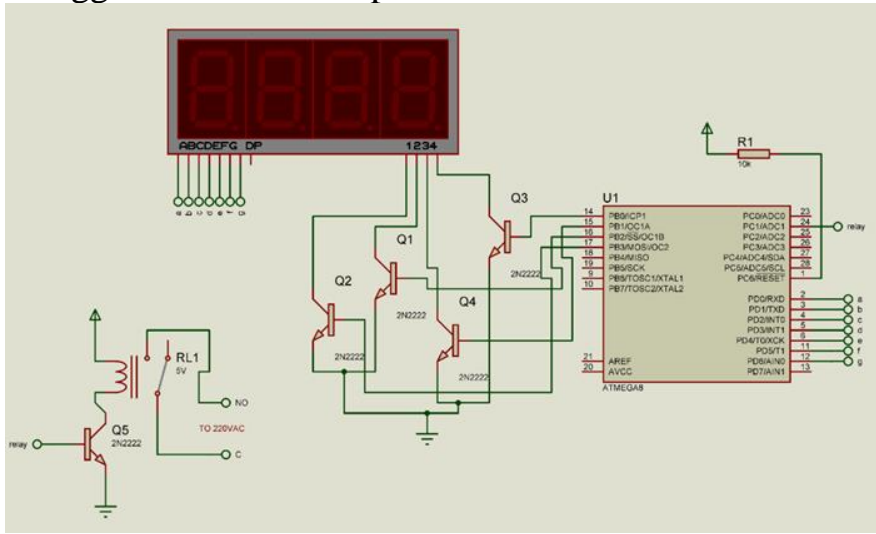

Gambar 3 Skema Rangkaian Timer Digital

Pada gambar 3 skema rangkaian timer digital komponen terpenting adalah IC Atmega 8, yang berfungsi sebagai pengendali dan output display. Output mikrokontroller pada port $b$ sebagai driver pengendali scaning pada 4 digit 7 segment, yang berupa transistor npn, karena 7 segment menggunakan common catode. Ketika basis diberi bias oleh mikrokontroller 1 atau 5 volt, maka transistor akan aktif kan menyalurkan common ke ground.

Pada port d sebagai output 8 bit yang akan menghidupkan led di 7 segment, yang berjumlah 7 led yang disusun dengan rapi. Port D.0-D.7 akan mengeluarkan logika 1 maka led 1 dot matriks segment akan hidup dan common digit terhubung ke ground, maka terbentuklah display yang telah disusun oleh program dengan tampilan angka 0-9, jika ada 4 segment, mikrokontroller bisa menampilkan 0-9999.

Program display yang ditampilkan adalah waktu hitung mundur yang berfungsi sebagai timer, dengan waktu yang telah diprogram adalah 2 jam, dengan tampilan 02:00, selama waktu 2 jam mundur, mikrokontroller mengaktifkan port c. 1 berlogika 1 untuk mengaktifkan relay lewat transistor bd139 berjenis npn, transistor npn jika basis diberi bias atau tegangan maka arus kolektor akan mengalir ke emitor(ground). Dengan ini relay bertegangan 5 volt melewati kumparan relay dan menuju ke ground, maka relay aktif dan menghubungkan kaki relay Common ke kaki NO. Relay ini menghubungkan tegangan PLN ke SMPS generator, maupun ke pompa generator.

\section{Rangkaian Display Control}

Membuat rangkaian mikrokontroller display output ozone dari ranges 0-100 dan pengontrol DAC binaryweighted 8 bit, terdapat dua saklar push button yang tersambung dengan ground dan resistor pullup sebagai input mikrokontroller untuk menaikan dan menurunkan digit display dari nol sampai seratus (0100). Gambar 4 adalah rangkaian display control:

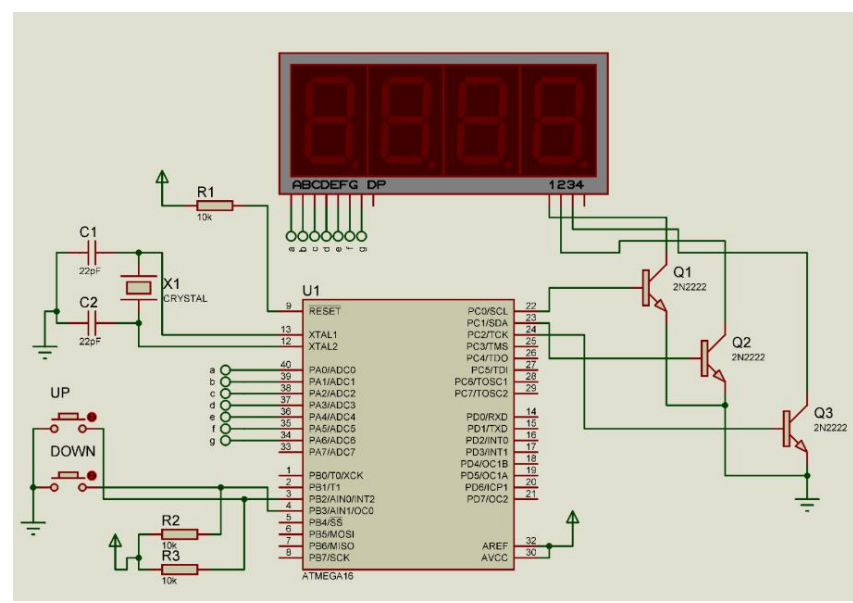

Gambar 4 Skema Rangkaian Display Control

Pada gambar 4rangkaian display control komponen sangat komplek terdiri dari IC Atmega 16, yang berfungsi sebagai pengendali dan output display. Output mikrokontroller pada port c sebagai driver pengendali scaning pada 3 digit 7 segment, yang berupa transistor npn, 7 segment menggunakan common catode. Ketika basis diberi bias oleh mikrokontroller 1 atau 5 volt, maka transistor akan aktif kan menyalurkan common ke ground.

Pada port a sebagai output 8 bit yang akan menghidupkan led di 7 segment, yang berjumlah 7 led yang disusun dengan rapi. Port D.0-D.7 akan mengeluarkan logika 1 maka led 1 bar segment akan hidup dan common digit terhubung ke ground, maka terbentuklah display yang telah disusun oleh program dengan tampilan angka 0-9, jika ada 3 segment, mikrokontroller bisa menampilkan 0-999.Program display yang ditampilkan adalah angka output gas ozon yang keluar, range nya dari 0-100. Setelah itu mikrokontroller memerintahkan port d sebagai output biner yang berupa decimal. Output yang keluar akan diproses ke system DAC binary weighted. 
Terdapat tombol UP dan Down yang terhubung dengan resistor pull up dan masuk ke input mikrokontroller port b.2 dan portb.3, jika tombol up di tekan, maka portb. 2 akan berlogika 0 , input di terima dan diproses mikrokontroller dengan perintah programnya display angka akan bertambah 1 .

Terdapat tombol Down jika tombol down di tekan, maka portb. 3 akan berlogika 0 , input di terima dan diproses mikrokontroller dengan perintah programnya display angka akan berkurang 1 .

Dalam pemograman juga terdapat EEPROM, yaitu fitur yang diberikan oleh ATMEL difungsikan sebagai memori program dan menyimpan data, jika power mati atau pln mati mikro menulis data ke memori EEPROM dan masih bisa menampilkan angka yang telah tersimpan.

\section{Rangkaian Control DAC \& Driver Switching}

Pada rangkaian DAC GAMBAR 5 dengan menggunakan system binary weighted yang terdiri dari resistor yang disusun parallel dengan pensaklaran menggunakan coupler. Output dari binary weighted tersebut sudah menjadi system analog, yang bisa digunakan untuk mengontrol osilator masuk ke basis transistor.Pada gambar 5 skema rangkaian control dac binary weighted, terdiri dari IC Atmega 16 output 8 bit yang terhubung ke masing masing resistor dari D7-D0, output dari mikrokontroller akan menghidupkan led optocoupler kemudian akan mensaklar resistor resistor yang telah ditentukan. Sistem DAC menggunakan sistem Binnary weighted. Pada pin 4 optocoupler terdapat kolektor yang di sambung secara parallel dengan yang lainnya dan terhubung ke Osilator Arduino pro mini.

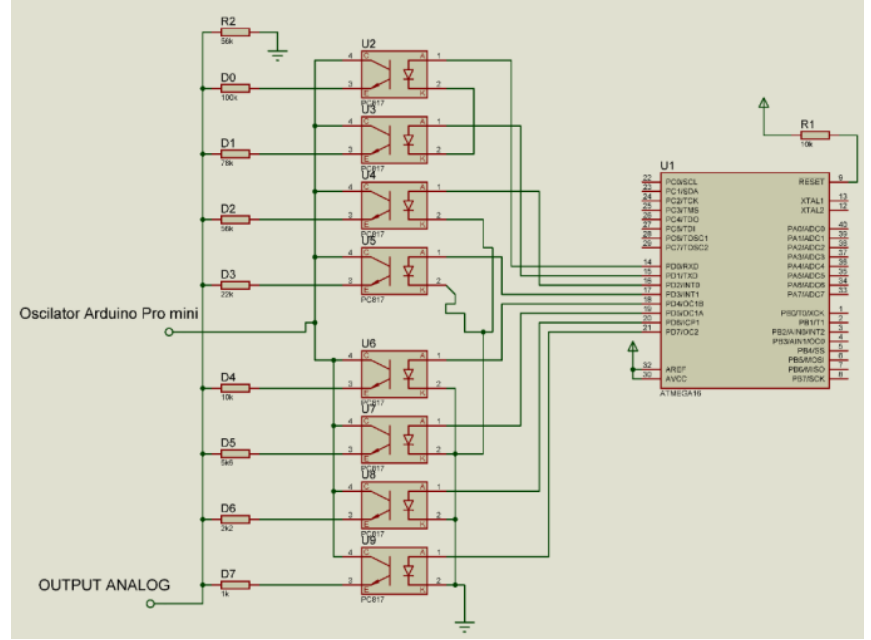

Gambar 5 Skema Rangkaian Control DAC Binary

\section{Weighted}

Pada gambar 6 skema rangkaian driven switching inverter high voltage Transformator/koil dirangkai secara seri dengan polaritas terbalik, dikarenakan plasma ozone dapat di hasilkan dengan senyawa yang terbentuk oleh plasma, hasil dari DAC diatas dapat dimasukan ke input analog transistor, transistor tersebut ada 2 tingkat penguatan, agar sinyal dari DAC $5 \mathrm{Vpp} 1 \mathrm{KHz}$ dapat ditingkatkan power (arus dan tegangan) Switching menuju ke ground pada transistor. Input basis transistor BD139 dihubungkan ke sistem DAC, kolektor Transistor tersebut mendapat VCC 24 volt, dan emitornya bertemu basis transistor power Transistor 2SC5200 agar penguatan 2 kali lipat dan transistor tersebut akan mensaklar dari VCC koil dan koil menuju ground sesuai frekuensi yang ditentukan.

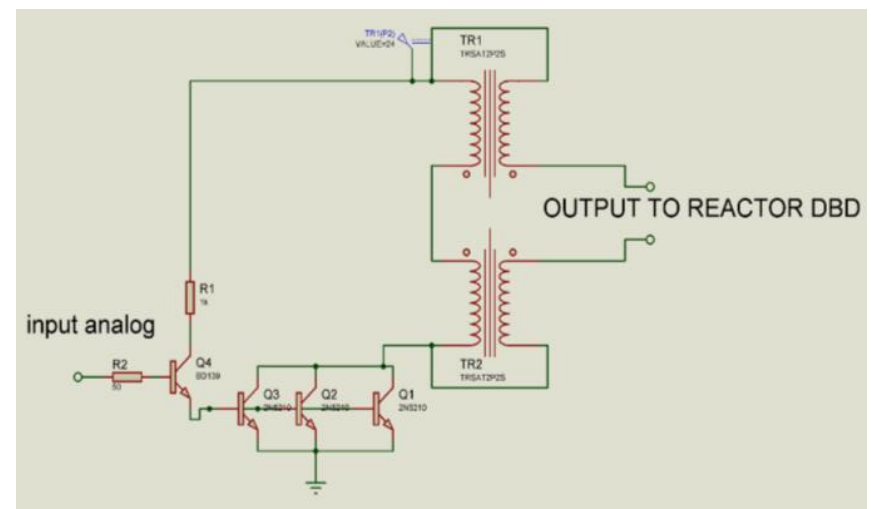

Gambar 6 Skema Rangkaian Switching Inverter High Voltage

Setelah semua terintegrasi dengan output dari transformator / koil dihubungkan ke elektroda reaktor plasma DBD (dielectric barrier discharge), setelah itu terdapat pompa udara sebagai pendingin dan penghasil udara senyawa gas oksigen, meskipun tidak $100 \%$ oksigen, akan tetapi diudara disekitar kita dapat menjumpai $20 \%$ oksigen di udara bebas. Pembentukan ozon membutuhkan gas oksigen $\left(\mathrm{O}_{2}\right)$.

\section{Pembangkit frekuensi}

Arduino minipro sebagai pembangkit pulsa osilator, frekuensi bervariasi tergantung pemakaian dan beban reaktor DBD, semua sudah terprogram dan terintegrasi secara sistem

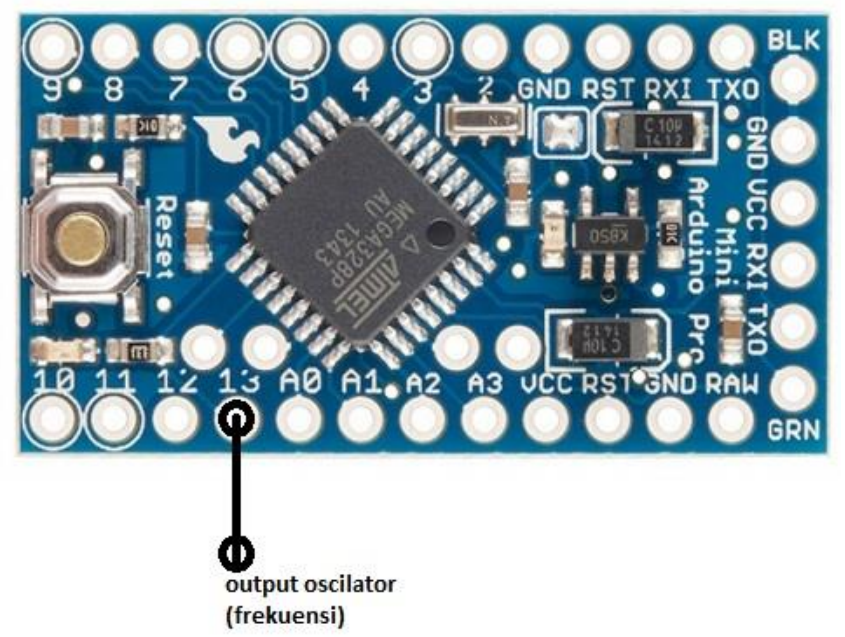

Gambar 7 Rangkaian Arduino Pro Mini 
Pada gambar 7 adalah rangkaian arduino pro mini. Vcc akan terhubung ke tegangan 5 volt. Terdiri dari beberapa pinout, dengan pin 13 sebagai output pembangkit frekuensi(osilator) bervariasi dengan program antara $1000 \mathrm{~Hz}-1500 \mathrm{~Hz}$.

\section{HASIL DAN PEMBAHASAN}

\section{Pengujian Uji Timer otomatis}

Rangkaian Timer diberi tegangan sebesar 5 volt dc. Pada 7 segment akan menampilkan angka yang telah di beri program sebagai berikut

$\mathrm{Jam}=2$

Menit $=00$

Jam_pul = Jam / 10

Jam_sat $=$ Jam Mod 10

Portb $=\& \mathrm{H} 01$

Portd = Lookup(jam_pul , Angka)

Waitms 5

Portb $=\& \mathrm{H} 02$

Portd = Lookup(jam_sat , Angka)

Waitms 5

Angka:

Data \&B00111111 ，\&B00000110 , \&B01011011 , $\& \mathrm{~B} 01001111, \quad \& \mathrm{~B} 01100110, \quad \& \mathrm{~B} 01101101$, \&B011111101 , \&B00000111 , \&B01111111 , \&B01101111

7 segment akan menampilkan jam 2 dan menit 00, jam_pul menampilkan jam dibagi 10 menampilkan 2, jam_sat menampilkan hasil sisa pembagian 10. Look up portd akan melihat dari olahan angka secara berurut dan program sesuai jam. Pada angka 2 seven segment menampilkan 02:00, dengan digit ke 2 dengan data angka biner 01011011 muncul angka 2 karena pada 7 segment terdapat pin

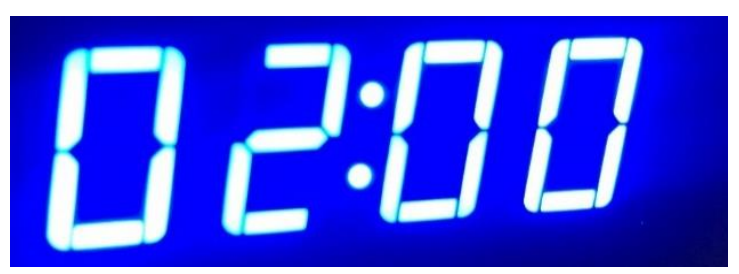

Gambar 8. Display Timer pada Jam 02:00

Gambar 8 menampilkan angka 0200 yaitu angka selama 2 jam counting down sampai menampilkan display 00:00 setelah waktu sudah lebih 2 jam display menapilkan 23:59

Biner 01011011 yaitu pada kaki led 7 segment a,b,g,e,d mendapat tegangan 5 volt untuk menghidupkan led dalam 7 segment, selain itu tidak bertegangan atau 0 volt, maka menjadi bentuk angka 2 .

If Jam $<=2$ And Jam $>=0$ Then

Portc. $1=1$

Else

Portc. $1=0$
End If

Timer bekerja selama 2 jam yang telah ditentukan, ketika jam kurang dari 2 maka portc. 0 akan mengeluarkan tegangan sebesar 5 volt. Tegangan 5 volt ini mengaktifkan relay bertegangan 5 volt dengan di drive dengan transistor 2n2222, tetapi jika jam lebih dari jam 2 maka relay akan mati karena output dari portc. 0 tidak mengeluarkan tegangan atau 0 volt. Timer bekerja dengan baik.

\section{Uji display kosentrasi}

Pada rangkaian display komponen sangat komplek terdiri dari IC Atmega 16, yang berfungsi sebagai pengendali dan output display. Output mikrokontroller pada port c sebagai driver pengendali scaning pada 3 digit 7 segment, yang berupa transistor npn, 7 segment menggunakan common catode. Ketika basis diberi bias oleh mikrokontroller 1 atau 5 volt, maka transistor akan aktif kan menyalurkan common ke ground.

Rangkaian display kosentrasi diberi tegangan sebesar 5 volt dc. Pada 7 segment akan menampilkan angka yang telah di beri program sebagai berikut

Count $=$ Data_count

$$
\begin{aligned}
& \text { Portc }=\& \text { H02 } \\
& \text { Porta }=\text { Lookup(rat }, \text { Angka }) \\
& \text { Waitms } 5 \\
& \text { Portc }=\& \text { H04 } \\
& \text { Porta }=\text { Lookup(pul }, \text { Angka) } \\
& \text { Waitms } 5 \\
& \text { Portc }=\& \text { H08 } \\
& \text { Porta }=\text { Lookup(sat }, \text { Angka) }
\end{aligned}
$$

Waitms 5

Angka:

Data \&B00111111 , \&B00000110 , \&B01011011 , $\& \mathrm{~B} 01001111, \quad \& \mathrm{~B} 01100110, \quad \& \mathrm{~B} 01101101$, $\& \mathrm{~B} 011111101, \quad \& \mathrm{~B} 00000111, \quad \& \mathrm{~B} 01111111$, $\& \mathrm{~B} 01101111$

7 segment akan menampilkan angka yang disimpan dalam eeprom, pada bilangan acak yang ditampilkan adalah 100. Rat(ratusan) menampilkan angka temp1 dibagi dengan 10 menampilkan angka 1, pada pul(puluhan) yaitu temp2 hasil sisa dari pembagian 100 yaitu akan menampilkan angka 0

Look up portd akan melihat dari olahan angka secara berurut dan program sesuai angka dengan ratusan/puluhan/satuan. Pada angka 1 seven segment dengan digit pertama dengan data angka biner 00000110 muncul angka 1 karena pada 7 segment terdapat pin. 


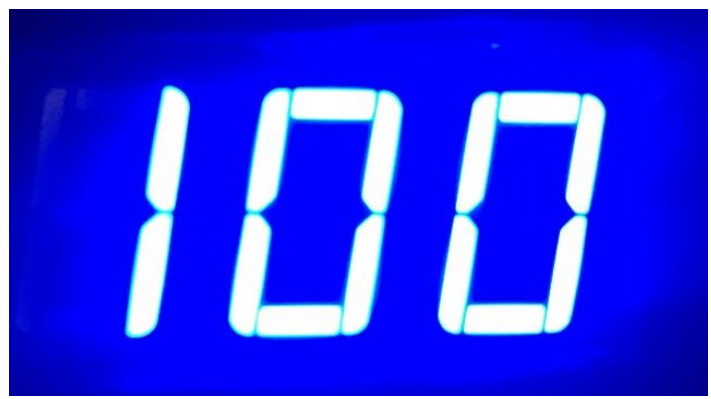

Gambar 9. Display Kosentrasi Menujuk Angka 100

Pada gambar 9 menampilkan angka 100 yaitu angka kosentrasi ozon yang keluar. Angka bisa menunjukan 0 sampai 100

Biner 00000110 yaitu pada kaki led 7 segment $\mathrm{c}$ dan d mendapat tegangan 5 volt untuk menghidupkan led dalam 7 segment, selain itu tidak bertegangan atau 0 volt, maka menjadi bentuk angka 1 .
If Pinb. $2=0$ Then
Count $=$ Count +1
Data_count $=$ Count
Writeeeprom Data_count , 1
End If
If Pinb. $3=0$ Then
Count $=$ Count -1
Data_count $=$ Count
Writeeeprom Data_count , 1
End If

End If

Portb. 2 dan portb. 3 terdapat saklar push on, di pin ic ini terdapat tegangan 5 volt yang terhubung ke VCC dengan resistor pull up, jika tombol porb. 2 mendapat ground maka display kosentrasi akan bertambah 1 , jika portb.3 mendapat ground maka display kosentrasi akan berkurang 1, dapat dilihat pada gambar 10 dan gambar 11.

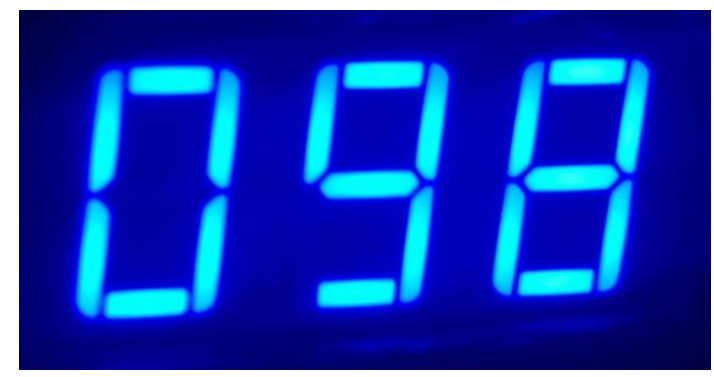

Gambar 10. Display Setelah Bertambah

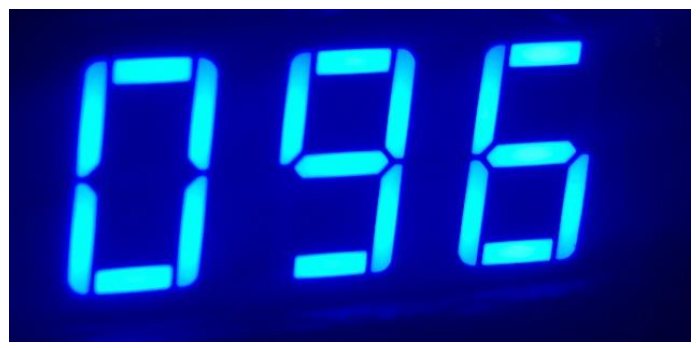

Gambar 11. Display Setelah Berkurang

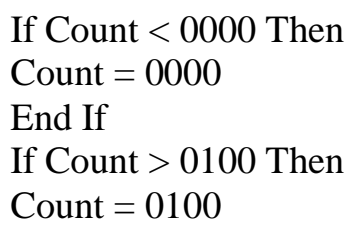

End If

Pada perintah tersebut adalah display kosentrasi (count) jika kurang dari 0 maka tidak bisa berkurang, dan jika lebih dari 100 akan tetap menampilkan 100

Portd $=$ Count $* 2$

Portd adalah hasil pengolahan kosentrasi dikali dengan 2, output 8 bit pada portd akan di konversikan ke sistem DAC.

Pada nilai 100, portd akan mengeluarkan biner yaitu 11001000, pada portd3, portd6 dan portd7 mengeluarkan tegangan sebesar 5 volt yang akan di input pada ic coupler sebagai switch resistor binary weighted. Otomatisasi mikrokontroller atmega 16 bekerja dengan baik.

\section{Pengujian DAC}

Hasil konversi DAC dengan perhitungan, perhitungan variasi DAC dan penguatan transistor.

\section{Hasil konversi Binnary to Decimal dan BINARY WEIGHTED RESISTOR (DAC)}

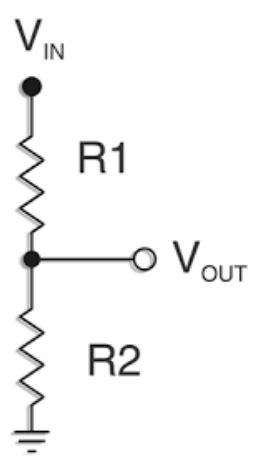

\section{Gambar 12. Resistor Voltage Devider}

Gambar 12. adalah gambar resistor di hubungkan secara seri kemudian diberi tegangan sebesar Vin. Antara R1 dan R2 terdapat tegangan output yang dapat di hitung.

Sesuai rangkaian rancang bangun, berikut data resistor DAC

$\mathrm{R} 2=56 \mathrm{~K}$

$\mathrm{D} 7=1 \mathrm{~K}$ ohm, D6 = 2K2 ohm, D5 = 5K6 ohm, D4 $=10 \mathrm{~K}$ ohm, $\mathrm{D} 3=22 \mathrm{~K}$ ohm, D2 $=56 \mathrm{~K}$ ohm, D1 = $78 \mathrm{~K}$ ohm, D0 $=100 \mathrm{~K}$ ohm, dengan perhitungan R1 paralel pada binary weighted.

\section{Kosentrasi 100 :}

Vout $=$ Vin $\times \mathrm{R} 2 /(\mathrm{R} 2+\mathrm{R} 1)$

Vout $=5 \mathrm{v}$ x 56000/(56000+666)

Vout $=4,941 \mathrm{~V}$ 
Tabel 1 Perhitungan Nilai Digital To Analog Converter

\begin{tabular}{|l|l|l|l|l|}
\hline $\begin{array}{l}\text { Kosentrasi } \\
\text { Display } \\
\begin{array}{l}\text { Adjustment } \\
(\%)\end{array}\end{array}$ & $\begin{array}{l}\text { Desimal } \\
\text { DAC }\end{array}$ & $\begin{array}{l}\text { D7-D0 } \\
\text { Biner }\end{array}$ & $\begin{array}{l}\text { Nilai } \\
\text { R1 } \\
(\mathrm{K} \Omega)\end{array}$ & $\begin{array}{l}\text { Vout } \\
(\mathrm{V})\end{array}$ \\
\hline 0 & 0 & 00000000 & - & 0 volt \\
\hline 1 & 2 & 00000010 & 78 & 2.089 \\
\hline 2 & 4 & 00000100 & 56 & 2.500 \\
\hline 4 & 8 & 00001000 & 22 & 3.589 \\
\hline 6 & 12 & 00001100 & 15 & 3.900 \\
\hline 10 & 20 & 00010100 & 8.4 & 4.32 \\
\hline 20 & 40 & 00101000 & 4.4 & 4.63 \\
\hline 35 & 70 & 01000110 & 2 & 4.82 \\
\hline 50 & 100 & 01100100 & 1.5 & 4.866 \\
\hline 64 & 128 & 10000000 & 1 & 4.91 \\
\hline 80 & 160 & 10100000 & 0.848 & 4.925 \\
\hline 90 & 180 & 10110100 & 0.771 & 4.932 \\
\hline 100 & 200 & 11001000 & 0.666 & 4.941 \\
\hline
\end{tabular}

Tabel 1 yaitu tabel yang berisi kosentrasi dari 0 sampai 100, kemudian terdapat Desimal DAC, output digital 8 bit menjadi desimal yaitu 255, maka maksimal desimal perhitungan 200 agar tidak melebihi 8 bit. Nilai R semakin mengecil dan menghasilkan Vout semakin besar.

\section{Pengukuran Pada frekuensi $1500 \mathrm{~Hz}$}

Tabel 2 Output Pengukuran pada Frekuensi 1,5 Khz

\begin{tabular}{|c|c|c|c|c|}
\hline $\begin{array}{c}\text { Kosent } \\
\text { rasi \% }\end{array}$ & $\begin{array}{c}\text { Tegan- } \\
\text { gan(KV) }\end{array}$ & $\begin{array}{c}\text { Arus } \\
(\mathrm{mA})\end{array}$ & $\begin{array}{c}\text { Kosen- } \\
\text { trasi Ozon } \\
(\mathrm{ppm})\end{array}$ & $\begin{array}{c}\text { Daya } \\
\text { (watt) }\end{array}$ \\
\hline 100 & 13.9 & 22.2 & 59 & 308.58 \\
\hline 75 & 13.9 & 22.1 & 56 & 307.19 \\
\hline 71 & 13.8 & 22.1 & 52 & 304.98 \\
\hline 63 & 13.4 & 20.1 & 50 & 269.34 \\
\hline 60 & 13.3 & 19.9 & 47 & 264.67 \\
\hline 53 & 12.9 & 18.2 & 44 & 234.78 \\
\hline 48 & 12.4 & 15.8 & 42 & 195.92 \\
\hline 42 & 11.5 & 10.2 & 40 & 117.3 \\
\hline 40 & 11.3 & 9.1 & 38 & 102.83 \\
\hline 39 & 11 & 8.1 & 37 & 89.1 \\
\hline 38 & 10.8 & 7.6 & 36 & 82.08 \\
\hline 37 & 10.7 & 7.4 & 35 & 79.18 \\
\hline 36 & 10.6 & 6.7 & 34 & 71.02 \\
\hline 35 & 10.3 & 5.9 & 33 & 60.77 \\
\hline 34 & 10.1 & 5.5 & 32 & 55.55 \\
\hline 30 & 8.9 & 3.8 & 30 & 33.82 \\
\hline 26 & 8.3 & 3.4 & 26 & 28.22 \\
\hline 23 & 7.5 & 3 & 24 & 22.5 \\
\hline 20 & 6.7 & 2.7 & 20 & 18.09 \\
\hline 17 & 5.8 & 2.3 & 15 & 13.34 \\
\hline
\end{tabular}

\begin{tabular}{|c|c|c|c|c|}
\hline 10 & 3.8 & 1.4 & 10 & 5.32 \\
\hline 5 & 2 & 0.7 & 0.6 & 1.4 \\
\hline 0 & 0 & 0 & 0 & 0 \\
\hline
\end{tabular}

Tabel 2 yaitu tabel Output Pengukuran pada frekuensi $1,5 \mathrm{Khz}$ yang berisi kosentrasi dari 0 sampai 100 , kemudian terukur tegangan dan arus menggunakan multimeter probe HV dan tang ampere. Output ozone yang dihasilkan semakin tinggi dan daya yang dibutuhkan semakin tinggi.

6. Hasil Pengujian Frekuensi Terhadap Daya

Tabel 3 Pengaruh Frekuensi Terhadap Daya

\begin{tabular}{|l|l|l|l|l|}
\hline $\begin{array}{l}\text { Frek- } \\
\text { uensi } \\
(\mathrm{Hz})\end{array}$ & $\begin{array}{l}\text { Kosen- } \\
\text { trasi } \\
100 \%\end{array}$ & $\begin{array}{l}\text { Kosentrasi } \\
53 \%\end{array}$ & $\begin{array}{l}\text { Kosen- } \\
\text { trasi } \\
10 \%\end{array}$ & $\begin{array}{l}\text { Kosen- } \\
\text { trasi } \\
0 \%\end{array}$ \\
\hline 1000 & $\begin{array}{l}157,5 \\
\text { Watt }\end{array}$ & $\begin{array}{l}120,75 \\
\text { Watt }\end{array}$ & $\begin{array}{l}1,7 \\
\text { Watt }\end{array}$ & 0 watt \\
\hline 1250 & $\begin{array}{l}274,77 \\
\text { Watt }\end{array}$ & 225,7 Watt & $\begin{array}{l}2,3 \\
\text { Watt }\end{array}$ & 0 watt \\
\hline 1500 & $\begin{array}{l}308,58 \\
\text { Watt }\end{array}$ & 234,78 Watt & $\begin{array}{l}5,32 \\
\text { Watt }\end{array}$ & 0 watt \\
\hline
\end{tabular}

Tabel 3 yaitu tabel pengaruh frekuensi terhadap daya, frekuensi semakin tinggi daya dan kosentrasi juga yang didapatkan semakin tinggi, semakin rendah kosentrasi daya akan menurun.

\section{Frekuensi Terhadap Daya}

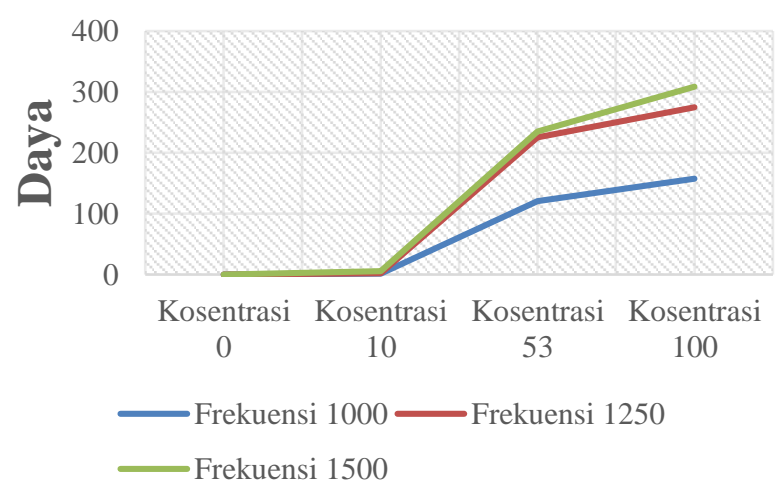

Gambar 13. Grafik Frekuensi Terhadap Daya

Pada gambar 13 grafik frekuensi terhadap daya yaitu semakin frekuensi tinggi maka daya yang dibutuhkan juga semakin besar, karena hal ini berbanding lurus dengan hasil ozon yang di produksi. 


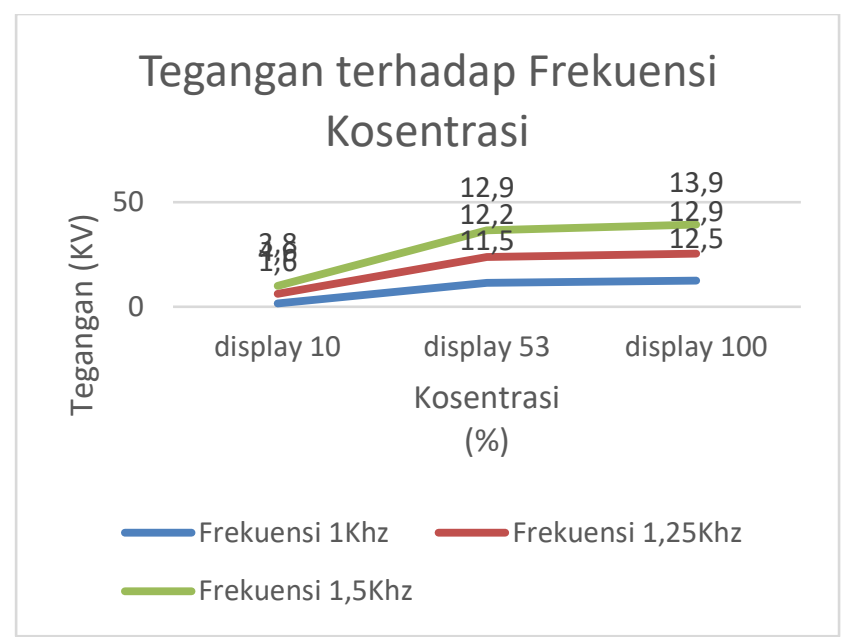

Gambar 14 Grafik Tegangan Output Terhadap Frekuensi

Gambar 14 Ditampilkan bahwa pada tegangan frekuensi $1 \mathrm{KHz}$ dengan variasi nilai tertinggi puncaknya adalah 12.500 volt, sedangkan pada frekuensi $1,25 \mathrm{KHz}$ dengan variasi nilai display tegangan puncaknya yaitu 12.900 volt, sedangkan puncak tertinggi adalah pada frekuensi $1,5 \mathrm{KHz}$ dengan tegangan 13.900 volt.

CPR (Centre for Plasma Research) menetapkan standar Tegangan reactor tidak boleh melebihi batas yaitu $12 \mathrm{KV}$ yang sangat dihindari dalam produksi ozone, dikarenakan akan ada gas lain yang terpecah yaitu nitrogen, nigrogen pecah di tegangan 12.500 volt yang akan menyebabkan muncul gas beracun yaitu gas NOx. Arus tidak boleh melebihi $20 \mathrm{~mA}$ dikarenakan akan overheat pada satu reactor DBD yang akan memproduksi ozon sebesar $60 \mathrm{ppm}$.

\section{SIMPULAN DAN SARAN}

\section{KESIMPULAN}

Rancang bangun generator ozone teknologi plasma DBD (Dielectric Barrier Discharge) dengan mikrokontroller ATMega 16 dapat ditarik kesimpulan bahwa:

1. Semakin tinggi kosentrasi display semakin tinggi tegangan outputnya.

2. Semakin tinggi frekuensinya semakin besar tegangan output dan ozon yang dihasilkan.

3. Pengendalian menggunakan teknologi mikrokontroller AVR pada generator plasma bekerja dengan baik dengan Efisiensi menggunakan sistem switching didapatkan $>90 \%$.

4. Timer bekerja dengan baik selama 2 jam.

\section{SARAN}

Untuk kedepannya bagi peneliti dapat mengembangkan Generator plasma ozon menggunakan teknologi IoT. Selain menggunakan transformator, di- harapkan penelitian ini dapat dilanjut dengan lebih ringkas (mobile). Teknologi ozone bisa dikembangkan lagi tidak hanya aplikasi di pangan, tetapi dibidang kedokteran yang membutuhkan setrilisasi menggunakan ozon atau bidang elektronika kedokteran.

\section{DAFTAR PUSTAKA}

[1] Assa'idah dan Yulinar Adnan.2009. Investigasi Terhadap Kemampuan 2 Tipe ADC. Universitas Sriwijaya: Palembang. Diunduh 24 april 2017.

[2] Fadhli, 2010, Rancang Bangun Inverter 12v Dc Ke 220vac Dengan Frekuensi 50hz Dan Gelombang Keluaran Sinusoidal, Depok : Universitas Indonesia.

[3] Herman, 2007, Elektronika Teori Dan Penerapan, Jember : Penerbit Cerdas Ulet Kreatif

[4] Ibrahim, KF, 1996, Teknik Digital, Andi Offset, Yogy akarta

[5] Nur. M, 2011, Fisika plasma dan aplikasinya, Semarang: Undip Press

[6]Waluyo, 2015 Perancangan dan Realisasi Generator Ozon menggunakan Metoda Pembangkitan Tegangan Tinggi Bolak - Balik (AC), Bandung 